ISSN No. 0974-035X

An indexed refereed \& peer-reviewed journal of higher education

Towards Excellence

UGC-HUMAN RESOURCE DEVELOPMENT CENTRE

Gujarat University, Ahmedabad-380009, Gujarat, India

\title{
UNDERSTANDING OF INTERCULTURALISM AND HUMAN SOLIDARITY IN M.G. VASSANJI'S NO NEW LAND.
}

\section{Dr Shaurya Brahmbhatt}

\begin{abstract}
Interculturalism refers to support for cross-cultural dialogue and challenging selfsegregation tendencies within cultures. Interculturalism involves moving beyond mere passive acceptance of a multicultural fact of multiple cultures effectively present in a society and instead promotes dialogue and interaction among cultures. Interculturalism has arisen in response to criticisms of existing policies of multiculturalism, such as criticisms that such existing multicultural policies had failed to create inclusion of different cultures within a society, but instead have divided society by legitimizing segregated separate communities that have isolated themselves and accentuated their specificity. It is based on the recognition of both differences and similarities among cultures. It has addressed the risk of the creation of absolute relativism in postmodernity and multiculturalism. Philosopher Martha Nussbaum in her work Cultivating Humanity describes interculturalism as involving "the recognition of common human needs across cultures and of dissonance and critical dialogue within cultures" and that interculturalists "reject the claim of identity politics that only members of a particular group can understand the perceptive of that group.
\end{abstract}

Keywords: Interculturalism, multiculturalism, dissonance, and identity politics

Moyez G. Vassanji was born in Nairobi, Kenya on 30th May 1950 to Gulamhussein Vassanji and Daulatkhanu Nanji. He was brought up in Dar es Salaam, Tanzania and went to the United States in 1970 to study physics at the M.I.T. (B.S. 1974). In 1978 he received a $\mathrm{PhD}$ in nuclear physics from the University of Pennsylvania and went to Canada. There he became affiliated with Atomic Energy of Canada (1978$80)$ and with the University of Toronto, where he worked as a research associate and lecturer in physics from 1980 to 1989 and published widely. In 1982 he founded and 
edited the Toronto South Asian Review (TSAR), which became the Toronto Review of Contemporary Writing Abroad in 1993. His interest in fiction is a long-standing one. In the course of his studies, for example, Moyez Vassanji translated Sanskrit poetry. He became a full-time writer in 1989, which was also the year his first novel The Gunny Sack was published to instant critical acclaim. In 1990 it won the Commonwealth Writers Prize for best book in the African region. In 1994 M.G. Vassanji won the prestigious Giller Prize for The Book of Secrets and was chosen as one of twelve Canadians on Maclean's Honour Roll. He has published four novels, The Gunny Sack (1989), No New Land (1991), The Book of Secrets (1994) and Amriika (1999), a collection of short stories, Uhuru Street (1992) as well as a collection of essays, A Meeting of Streams: South Asian Canadian Literature (1985). Vassanji lives in Toronto where he writes and teaches. He is married to Nurjehan Aziz, a laboratory researcher, and has two children, Anil and Kabir.

At the centre of Vassanji's fiction is the Indian Shamsi community, his fictional rendering of the Shia sect of the Ismailis.1 Historically, the Ismailis were colonial elite that supported the British and the German colonial rule in East Africa. Starting as shopkeepers and businessmen settling on the coast of British East and German East Africa, they possessed the necessary linguistic and political inside knowledge to assist the colonial administrations in ruling an inaccessible and unruly hinterland. Their role as marginal men lent them the flexibility to operate as cultural translators and to function as "a buffer zone between the indigenous Africans and the colonial administration." The Ismailis identified with the colonizers and were rewarded. As Vassanji writes in No New Land, it is not surprising

the idea of empire was relinquished slowly in the Asian communities. [. ..] The

Asians had spawned at least two knights of the empire in their slums, they had had Princess Elizabeth in their midst, greeted Princess Margaret with a tumultuous welcome. They spoke proudly of Churchill and Mountbatten, fondly of Victoria. What a schoolboy or girl had not heard over the radio the reassuring chimes of Big Ben before falling asleep, or the terrified voice of Dicken's Pip, the triumphant voice of Portia, the Queen's birthday message.1 
In postcolonial times, the position of the Indian communities in East Africa became untenable. Because of their affiliation with the former colonisers, the postcolonial regime marginalized the Asians of East Africa. With the nationalisation of rental properties in Uganda (under Idi Amin) and Tanzania, the former German East Africa, the Indian colonial elites of East Africa were forced into the international diaspora.

By narrating the story of the Shamsi community, Vassanji gives voice to a Canadian immigrant experience that hitherto has not found its way into literature and public awareness. No New Land illustrates the community's fate in Toronto where one of the protagonists, Nurdin Lalani, emigrates with his family. Nurdin Lalani, an average man, is regarded by his father as a useless "good-for-nothing" (19), an underachiever: "One brother making millions in the diamond business, the other making him - so Nurdin had heard - in the black market. Always he, Nurdin, the middle one, neither here nor there" (169). While he is a failure in Africa, Nurdin Lalani is also in an uneasy position in the Canadian diaspora. Thus No New Land can be said to detail "the ironies, the pathos and the hardships of having to live between two worlds, neither of which provides the harmony of a life that the mind imagines and craves for."

No New Land has as its central theme the tension "between assimilation and acculturation to mainstream Canadian culture, versus maintaining some kind of racial or cultural integrity brought over from the old land." 5 Canada is a land of opportunities but at the same time, it becomes the space of cultural dislocation. Already at an early stage, the novel alludes to the troublesome complexity the Canadian experience is fraught with. Thus the snow that Nurdin and his family encounter on entering Canada become metonymic of Otherness:

The snow had fallen, a blistering wind blew squalls on the road and, as they stepped outside the airport building, it made sails of their ill-fitting second-hand clothes, which had seen better days on the backs of colonial bwanas and memsahibs on chilly African evenings. "So this is snow," Zera remarked. It had been cleared into unimpressive mounds and at their feet was a fine powder blown about by reckless gusts. Toes freezing, faces partly paralysed, eyes tearing, they stood outside, 
shoulders hunched. The two children were moaning and shivering, weeping, hiding behind adult coats, creating fresh pockets and exposing fresher areas of anatomy for the wind to snatch at. (35)

Symbolically, snow foreshadows the emotional coldness of the metropolis rather than the potential of the unknown in realising ambitions and dreams. Later on, the whiteness of the snow is juxtaposed with the whiteness of the immigration official's colour of skin: "Finally someone welcoming you, a white man welcoming you. Finally a place to lay down your head" (34). While the hostility of the weather anticipates that Canada is a country causing alienation and isolation for Nurdin and his family, the warm reception by a white man immediately triggers colonial fantasies and desires inherent in the psychological dispositions of the members of a colonial elite decolonised against its will. Taken together, the symbolic undercurrent suggests that Canada takes on the paradoxical quality of a dream and a nightmare at the same time. The Canadian diaspora is invested with desire and hope but, with few exceptions, delivers only disappointments and disillusionment. While Canada holds in store many frustrations, Canada can also be said to offer possibilities to the immigrant. However, one of the ironies pervading No New Land is that the novel's protagonist fails to seize them.

M.G. Vassanji's novel conveys the immigrant experience in terms of cultural retention on the one hand and systemic marginalisation on the other. After they arrive in Canada, Nurdin and his family have trouble finding accommodation. Eventually, they move to Don Mills where various members of the community who have migrated to Canada before now live under appalling circumstances, cherishing the "illusion of 'home' and shelter from an alien society."7 While Nurdin and his family continue to live in the same way culturally and socially, they overlook that their social networks are confined to an enclave. Cultural practices are not translated but simply transplanted to a new cultural context. A case in point is the A-T shop of Dar which finds its emulation in the community's meeting place in Don Mills (cf. 28and 71). Nurdin's failures in the new land frequently draw him towards the familiar, i.e. the cultural security that the Canadian simulation of the A-T shop guarantees. 
It is crucial to realize that the novel suggests that Nurdin's mimicry is not merely inauthentic but also inadequate in a new land. This has to do with the assumption of culture Nurdin operates on. For the utopian potential of the promised land of Canada to be realized it needs the immigrant's participation. The familiarity of Don Mills and the retention of indigenous culture accompanied by it may be comfortable; however, in the context of the novel it is also dangerous because the familiarity offered does prevent the immigrant from making an effort to engage with (perhaps even to adapt to) the foreign environment. An understanding of culture as essence is thereby implicitly refuted. Acceptance and mutual understanding among the members of the Shamsi community inside the block of apartments in Don Mills must not supersede the culture outside. This is a danger that also Neil Bissoondath cautions us against when he writes that
Vassanji's the description of this community of exiles - so tight, so self- contained, so alienated from the mainstream - is that of an almost classic ghetto. It is not an extreme of multiculturalism but its ideal: a way of life transported whole, a little outpost of exoticism preserved and protected. 8

The security granted by the culture taken over from East Africa is restricted to the house, (at least in the Western literary tradition) a traditional symbol of shelter as well as of psychosocial sanity and hygiene. While it has its advantages, the image of the house also indicates a limitation. The danger is of Don Mills becoming a system of its own, and a system without permeable boundaries at that. If culture is a negotiation, then the Shamsis living in Don Mills fail to recognise the importance of cultural exchange, and thereby run the danger of replicating the purist stance towards the culture that characterised the community's attitude in East Africa (cf. 712). Vassanji implies that in Canada both the culture brought over (and cherished inside) and the culture encountered (and neglected outside) are, in theory, at the immigrant's disposal. In Vassanji's eyes, however, opting for one over the other is revealed to be at worst fatal and at best erroneous. The question as to which side to privilege over which becomes a pressing one for Nurdin and other members of the South-East Asian communities of Toronto. It thus seems safe to suggest that at the heart of No New Land is the interrogation of how much retention is necessary and 
unproblematic and how much adaptation is called for an essential in a multicultural context.

While I have taken the issue of accommodation as a critique of cultural retention on an individual level, Vassanji's novel allows for an alternative reading that sees the reasons for Nurdin's eventual failure to adapt less in individual shortcomings than in structural limitations of the society he has migrated to. The ghetto of Don Mills could be read as an aspect of the underside of Canadian multiculturalism that cannot prevent cultural difference from taking on the aspect of social injustice. Canada's multicultural policy of cultural unity in cultural diversity may also disguise social gulfs. Social class transforms the ideal of the cultural mosaic into a socio-economic vertical mosaic.

No New Land calls for a balanced interpretation. The novel enacts the tension between structural/social and individual shortcomings in the multilateral process of adaptation without resolving them. Nurdin and his family do not want to face the new, i.e. Canadian reality, head-on. In that, they are to be criticized. However, No New Land also testifies to the new land's systemic flaws, something which calls for a more complex reading of the migrant experience in Canada. To determine the factors that thwart Nurdin's migrant experience, one must take into account that individual and structural shortcomings are equally responsible for his failure. In Vassanji's novel no reading prevails over the other, both interpretations are true to a certain extent. The inscription of profound ambivalence is Vassanji's major artistic achievement in his second novel. It is a narrative strategy that informs many episodes in No New Land, the most striking of which interrogates the relevance of race as a marker of difference.

Nurdin's flaw and the structural problems of Canadian multiculturalism overlap in that both rely on race as a conceptual tool. There are two instances of racism in No New Land. The first concerns Esmail who initially is discriminated against and eventually beaten up in a Toronto subway station (cf. 95-8). His fate attracts the attention of the media, and the nobody Esmail becomes a celebrity, a somebody. Cynically enough, not until he is victimised does he receive the recognition of his Canadian host society. Due to the racism of an allegedly non-racist Canada, Esmail begins to paint 
indigenous masks and thereby makes ethnic difference his only artistic theme. Racial violence triggers a return to indigenous art as a means of coping with aggressive Othering. Speaking about the inspiration for Esmail's coming-out as an artist, Jamal and Nanji comment: "'Dar didn't do it - Canada did.' 'By breaking his legs, you mean'” (164).

By being violently discriminated against, the hitherto apolitical Esmail is politicised. He leaves Canada for the country of his birth, Tanzania, while continuing to paint. His return to his origins is not only an aesthetic endeavour, but it also has a sociological dimension in that it brings about a valorisation of (his) community as well as a valorisation by his community, the Shamsis. Not only has his art benefitted from his return home, but Esmail's apocalyptic self-expression is also better understood by the members of the community he belongs to than by a Canada that rejects his works as aesthetically inferior. When connected to their socio-cultural context, the masks he paints acquire additional layers of meaning because they have a particular cultural/ritual function within Tanzanian society. The fact that Esmail's art has not been understood by Canada reflects not only how impoverished his art may have appeared to a first-world audience but also how rootless he is in North America. In this context, his new role as an artist preoccupied with a community's culture and collective memory also has a therapeutic function for himself.

Esmail ends his dislocation and disorientation by giving up his struggle to make Canada home. But it must not be concluded from this that his story is, therefore, that of a failure. While on the one hand his story, due to the structural shortcomings of a Canadian multicultural policy, is that of a thwarted adaptation, Esmail, on the other hand, succeeds economically, which renders his fate ironic. As a human being, Esmail is rejected in Canada because of his ethnic difference; as an artist in Africa, however, he is eventually embraced by an international postcolonial art history establishment eagerly responding to the ethnic difference reflected in his art: "Students - American students, nice pretty girls - go and study this art" (163). While Canadian culture has failed him by aggressively harping on his alleged essential difference, racism proves a blessing in disguise at least money-wise. Involuntarily, Esmail is made to discover the cultural capital inherent in the very difference constructed to marginalize him. 


\section{Works Cited}

Hall, Stuart. "Negotiating Caribbean Identities", Postcolonial Discourse .Ed.Gregory Castle, Oxford: Blackwell Publishers, 2001. Print \& Web

Birbalsingh, Frank. Ed. Jahaji: An Anthology of Indo-Caribbean Fiction. Toronto:

TSAR Publications, 2000. Print

Paranjape, Makarand ed. In Diaspora: Theories, Histories, Texts. New Delhi :

Indialog Publications Pvt. Ltd., 2001. Print

Cohen, Robin. "Diasporas and the Nation-State: From Victims to Challengers." International Affairs (Royal Institute of International Affairs 1944-) 72.3 (1996): 507-520. Ethnicity and International Relations, Web. 21 February 2014.

Clifford, James. "Diasporas." Cultural Anthropology 9.3 (1994): 302-338.

Blackwell Publishing. Web. 7 January 2014.

Gill, Stephen. 'Mythical Interpretation of Indo-Canadian Diaspora' Immigrant. Ontario: Vesta Publications Ltd., 1982. Print

Vassanji, M. G. Uhuru Street Toronto : Mclelland and Stewart Ltd.1991.

---. No New Land. Mclelland and Stewart Ltd. 2012.

\section{Dr Shaurya Brahmbhatt \\ Assistant Professor, Department of English \\ The Maharaja Sayajirao University of Baroda, Vadodara Email: Shaurya.b-eng@msubaroda.ac.in}

